\title{
Vertebral Joint
}

National Cancer Institute

\section{Source}

National Cancer Institute. Vertebral Joint. NCI Thesaurus. Code C49577.

Any of the joints associated with the vertebral column. 